International Journal of Physical Sciences and Engineering
Available online at http://sciencescholar.us/journal/index.php/ijpse
Vol. 2 No. 3, December 2018, pages: $10 \sim 22$
e-ISSN : 2550-6943, p-ISSN : 2550-6951
https://doi.org/10.29332/ijpse.v2n3.192

\title{
Energy Analysis for Designing Photovoltaic Power Plant in Building of the Faculty of Mathematics
}

\author{
CrossMark \\ Lenin Agustin Cuenca Alava a , Guillermo Antonio Loor Castillo b, Julio Cesar Mera Macias c,
Julio Cesar Guaman Segarra d, Lucio Alfredo Valarezo Molina e
}

Article history: Received 15 April 2018, Accepted: 25 August 2018, Published: 12 September 2018

\section{Correspondence Author a}

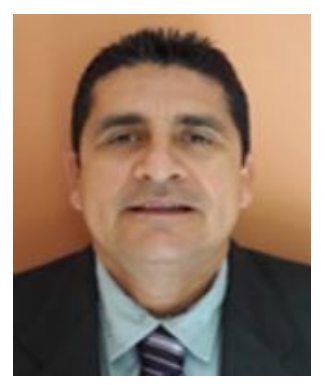

Keywords

Energy quality;

Micro-grid;

Photovoltaic energy;

Specific productivity;

Sustainable energy;

\begin{abstract}
It presents an analysis linked to one of the sustainable energy alternatives that are currently being adopted with worldwide success. Putting the field research method into practice. The results of a study related to an application of technological innovation to reduce the amount of the electricity bill in the building of the Faculty of Mathematical, Physical, and Chemical Sciences (FCMFQ), by introducing photovoltaic technology connected to the network of the low tension of the institution. The results of the study of load and hourly consumption of energy of the entity are shown and an own methodology is deployed for the technological design of a photovoltaic power plant connected to the network, which can avoid the consumption of energy of the conventional network, reducing the amount of the electric bill of the faculty, managing to reduce losses, improve the quality of electric service and reduce $\mathrm{CO} 2$ emissions into the atmosphere.
\end{abstract}

e-ISSN: 2550-6943, p-ISSN: 2550-6951 @Copyright 2018. The Author. SS Journals Published by Universidad Técnica de Manabí. This is an open-access article under the CC BY-SA 4.0 license (https://creativecommons.org/licenses/by-sa/4.0/) All rights reserved.

\section{Contents}

Abstract 10

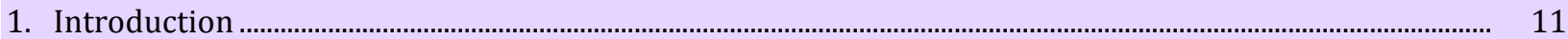

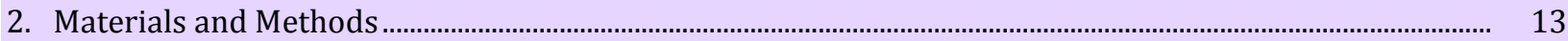

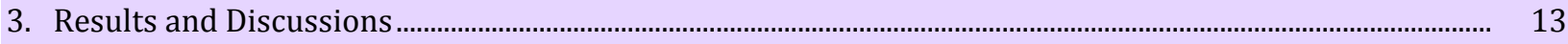

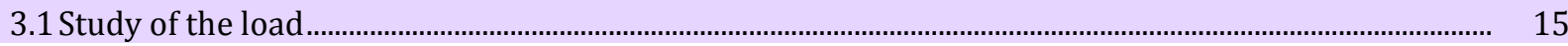

a Electrical Engineering Career, Universidad Tecnica de Manabi, Portoviejo, Ecuador

b Electrical Engineering Career, Universidad Tecnica de Manabi, Portoviejo, Ecuador

c Electrical Engineering Career, Universidad Tecnica de Manabi, Portoviejo, Ecuador

d Electrical Engineering Career, Universidad Tecnica de Manabi, Portoviejo, Ecuador

e Electrical Engineering Career, Universidad Tecnica de Manabi, Portoviejo, Ecuador 
3.2 Study of solar potential...

3.3 Market research.

4. Conclusion.

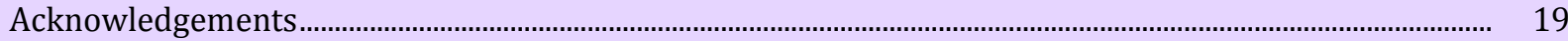

References

Biography of Authors..

\section{Introduction}

The man has not always used oil as a preferential source of energy. It is estimated that during the 6th century BC with the beginning of the Neolithic era, the man began to control and rationally use energy in agriculture, as well as the use of animals for work and food preparation. In the fourth and third centuries BC, the first major energy systems in history began, with the construction in the rainy areas of the Tigris, the Euphrates, and the Nile, of irrigation systems for crops. Around this same time, an elementary machine for the lifting of weights based on the lever principle (Rodríguez et al., 2012) was built.

Electric power is undoubtedly the most widely used resource in the world, it is a technical element that is given a vital importance for social development, however the intensive use of fossil fuels (oil, gas, and coal), encourage depletion of its reserves, while polluting effects can be accumulated that put at stake the stability of life on Earth (Saltos et al., 2016).

Between the 12th and 17th centuries, there was a strong demand for energy for the processing and preparation of metals, which considerably increased the demand for wood to be used as fuel. All this led to an inordinate advance in deforestation in many European regions. It is precisely in the seventeenth century, when as a result of mismanagement in the use of wood as fuel, there is an acute shortage of this resource in Western Europe, especially in the British Isles, where for the realization of industrial activities that are derived from thermal energy, had to start burning coal (Saltos et al., 2017).

From the seventeenth century, the first industrial revolution began to develop, with the emergence of technologies such as the steam engine, railroad, and textile machines, producing the first energy transition, where wood and charcoal are replaced by mineral coal. Some centuries later between 1860 and 1930 the second energy transition linked to the second industrial revolution took place, where electrical systems, aviation, and steel were introduced. In this stage, the mineral coal yields the preferential use of oil. By 1859, the first well for oil extraction in Pennsylvania had been dug by the Seneca Oil Co. (Saltos, Intriago et al., 2017).

In a short period of time already in the second half of the nineteenth century, the share of oil in the global primary energy market had rapidly increased, and by 1970 it formed the basis of the first global energy supply system (Rodríguez et al., 2017). During the second half of the 20th century the participation of fossil fuels in the generation of energy continues to increase and when the scenario of the new energy policies is described, it is proposed that the global energy demand registers a strong increase and can increase one third from 2010 to 2035 (Vázquez et al., 2017).

The combustion of fossil fuels is responsible for producing $80 \%$ of carbon dioxide $\left(\mathrm{CO}_{2}\right)$ emissions into the atmosphere, generating global warming. Some organizations have published information that reveals the danger posed by the burning of coal, oil and natural gas, because the historical level of $\mathrm{CO}_{2}$ in the atmosphere, had been at levels between 180 to $280 \mathrm{ppm}$ and in little more than a hundred years has been elevated to 400 ppm, a situation that, if not controlled, can generate a true global climate calamity (Dávila et al., 2017).

The increase in the excessive dependence on fossil fuels to obtain energy was leading to the depletion of their reserves, to such an extent that it is estimated according to a study published by the Organization of Petroleum Producing Countries (OPEC), which could fail to supply of oil for the year 2037 and, on the other hand, with a high degree of complexity due to the danger posed by the burning of coal, oil and natural gas for the environment and the human species (Cabeza, 2018). As a possible response to these natural impacts and the preservation of man's own life, a social commitment arises that is sufficiently understood by most human beings, who are committed to a scheme of progress that at the same time is respectful of nature and the environment. human integrity, that is to say, it is projected by a sustainable development, that enhances,

Alava, L. A. C., Castillo, G. A. L., Macias, J. C. M., Segarra, J. C. G., \& Molina, L. A. V. (2018). Energy analysis for designing photovoltaic power plant in building of the faculty of mathematics. International Journal of Physical Sciences and Engineering, 2(3), 10-22. https://doi.org/10.29332/ijpse.v2n3.192 
among other elements, the renewable sources of energy, which some time ago were not thought to have such an important participation in what refers to the generation of electricity (Van, 2002).

International discussions about the causes and implications for humanity of the so-called "greenhouse effect," caused by the increasing emissions to the atmosphere of gases such as $\mathrm{CO}_{2}$, reflect the need for an integrated approach in the treatment of environmental and environmental problems. Development, as well as the need, is for concerted action by the international community to mitigate the effects of global warming (Cabeza, 2018). Some years ago it has been strongly suggested that renewable energy sources that replace fossil fuels must be cleaner and must not produce more impacts that accelerate climate change. It is emphasized that as an additional advantage they should be located easily, with the least impact on the landscape and environmental conditions (Van, 2002).

The answer lies in the environment: sunlight, wind, water, plants, and the heat of the Earth. Some of these sources are very old. Since humans learned to make fire they used wood to achieve heating and cooking. The windmills helped to irrigate the fields of the ancient Persians. The ancient Greeks and Romans used the water that fell to turn hydraulic wheels. However, at the beginning of the 20th century in many places, the supposedly cheaper fossil fuels replaced almost all of these traditional sources of energy supply (Rodríguez et al., 2013).

On Earth, solar radiation is the main source of primary energy, which is converted into electrical energy by photovoltaic conversion. Practically it is inexhaustible, non-polluting, it is territorially distributed, and its potential availability is much higher than the energy needs of man (Giraudy et al., 2014). Unlike fossil fuels, solar energy does not produce carbon dioxide and therefore does not contribute to global warming. The most important thing is that, unlike increasingly scarce fossil fuels, this source of energy will never end while there is a man on the planet (Sarmiento et al., 2014). Worldwide there is a growing awareness of the importance of renewable energy and energy efficiency, which are an alternative not only to address climate change but to create new economic opportunities and provide access to energy billions of people (REN 21, 2015).

During the past decade, and particularly in recent years, advances have been made in renewable energy technologies, increases in generation capacity worldwide, as well as rapid cost reductions thanks to the support provided by economic policies, which have attracted a significant amount of investment and driven down costs through economies of scale (REN 21, 2015). In 2014, renewable energy continued to develop, even with the increasing consumption of energy worldwide and the dramatic decline in oil prices during the second half of 2015 as a backdrop. Also in 2014, renewable energy expanded significantly in terms of installed capacity and energy produced; while investments in renewable energy in the energy sector exceeded the net investments for fossil fuel power plants. The fastest growth and the most substantial increase in renewable capacity worldwide was seen in the electricity sector, the dominant technologies were: wind, solar photovoltaic (PV) and hydropower (REN 21, 2015).

Support for renewable energy policies has contributed to the growth of market volume and high global competition. Significant reductions in costs, especially for solar PV and wind, have played a role in the increasing electrification of transport and heating appliances. This fact has also highlighted the potential for greater overlap between sectors in the near future. In many countries, renewable energies are highly competitive with conventional fuels, particularly in the electricity sector (REN 21, 2015).

In developing countries, distributed power generation systems offer an unprecedented opportunity to accelerate the transition to modern energy services and increase access (Cabeza, 2018). For its part, the Ecuadorian government is closely following the use of renewable energy sources with hydro, wind and solar generation projects in various sectors of the country. But the national committee is still focused on the use of its water potential with large projects and investments. In Loja, the Villonaco Wind Farm is the largest project of its kind in the country, with 11 wind turbines installed that provide power to the medium voltage distribution network. This equipment will generate 16.5 MWh and its contribution to the country will be $0.03 \%$ to the National Interconnected System, being able to avoid the emission of 38,000 t $\mathrm{CO}_{2}$; as well as the import of a significant volume of diesel. These projects are driven by renewable energy (Hernández et al., 2017). Ecuador has been in tune with the latest in photovoltaic and thermal technology. As an example, the Government implemented photovoltaic solar panels in eight communes of the Gulf of Guayaquil. The Eurosolar project aims to provide electricity to 91 isolated and poor communities with the help of the European Union. Although other projects are being developed through the introduction of installations greater than $500 \mathrm{kWp}$, (Vázquez et al., 2016). However, the contribution of photovoltaic systems connected to 
the low voltage network in the distributed generation mode is still poor and its essence and objectives are not adequately understood.

To obtain the expected results in a photovoltaic project, certain factors must be considered, which must be studied and analyzed in detail. The main thing to assess is the energy efficiency of the photovoltaic system to be installed, to achieve this, different elements that are related must be evaluated, such as the dimensions of the installation area of the technology, the average potential of the daily solar energy, the angle of inclination of the modules, the level of shading present in the area, the quality and characteristics of the technology offered, the evaluation of the possible damages caused by natural disasters and other aspects that can be analyzed in a particular way (Vázquez et al., 2016).

The objective of the research is to offer a sustainable alternative to the problem of energy supply, where the results of the design of a grid-connected photovoltaic system are exposed in the new building of the Faculty of Mathematical, Physical and Chemical Sciences, which offers the possibility of reducing the dependence on oil in the generation of electricity, contributing to the reduction of $\mathrm{CO}_{2}$ emissions into the atmosphere.

\section{Materials and Methods}

The basic method used is exploratory, in order to determine a group of data and situations that were unknown, among which are: The hourly consumption of electrical energy in the building; the solar potential incident at the installation site and; the specific products that can be achieved. The method of a descriptive investigation was also used since information has been obtained about the electrical consumption of the installation, as well as the role that photovoltaic technology can play in the reduction of the economic impact, while at the same time-saving resources and the reduction of $\mathrm{CO}_{2}$ emissions into the atmosphere.

The traditional theoretical methods were operated, among them: The analysis-synthesis method in the study of bibliographic references; the historical-logical for the offering of precise thoughts related to the logic of scientific-technical development in the subject related to the study of photovoltaic technology and the role it can play in reducing the electricity bill. The method of induction and deduction that allowed, from the presence of the content of the object of study to the elaboration of own conclusions, making it possible to provide the particularities and proposed solutions. The theoretical-mathematical method to demonstrate from the theory, the efficiency of the technical procedure for the checking and control of the models linked to the design of the photovoltaic power plant. In general, investigative techniques were used to review documents, texts, theses, books, newspapers, magazines, technical standards, web pages, and manuals, in order to obtain the appropriate and clear information for the proper development of the topic addressed.

\section{Results and Discussions}

To carry out the study, it was decided to apply a survey to the workers and students who perform their work in the building under study, particularly the techniques used corresponded to the interview with the professors and students of the electrical career in order to know their knowledge related with energy education, renewable sources of energy, photovoltaic energy and efficiency.

For the interview, the population is made up of 12 professors and specialists of the career, the sample will consist of 9 teachers and specialists who will be interviewed. Given the characteristics of the population, no equation is required to define it. The population of students and professors of the race to apply the survey is 500, to select the sample the Larry-Murray equation was used (Murray and Larry, 2009).

$$
\mathrm{n}=\frac{\left(Z^{2}\right)(P)(Q)(N)}{\left(Z^{2}\right)(P)(Q)(N)\left(e^{2}\right)}
$$

Alava, L. A. C., Castillo, G. A. L., Macias, J. C. M., Segarra, J. C. G., \& Molina, L. A. V. (2018). Energy analysis for designing photovoltaic power plant in building of the faculty of mathematics. International Journal of Physical Sciences and Engineering, 2(3), 10-22. https://doi.org/10.29332/ijpse.v2n3.192 
Where:

$\mathrm{n} \rightarrow$ Sample size

$\mathrm{Z} \rightarrow$ Confidence level (1.96)

$\mathrm{P} \rightarrow$ Probability of occurrence (0.5)

$\mathrm{Q} \rightarrow$ Probability of non - occurrence (0.5)

$\mathrm{N} \rightarrow$ Population or universe (500)

The interview was applied to seven professors of the Electrical Engineering degree, focused on obtaining relevant information regarding photovoltaic technology. The technical instrument used to support the interview. Regarding the possibility of improving the electricity service by applying photovoltaic technology, the results are shown in figure 1, where the opinions provided by the specialists are shown in terms of the possibility of improving the electric service by applying photovoltaic technology.

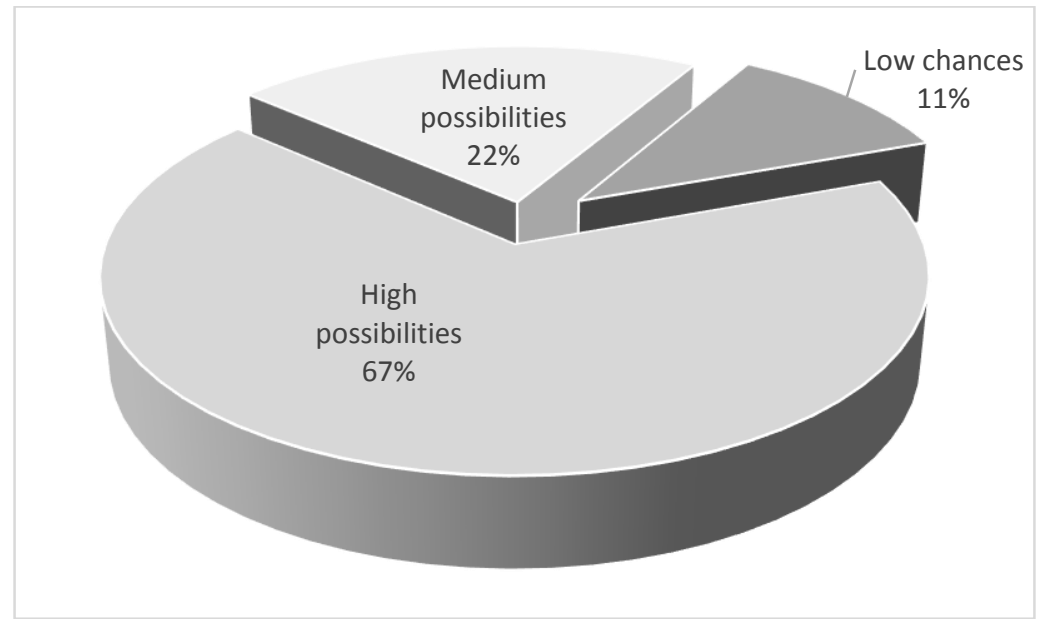

Figure 1. Opinions contributed by the specialists

It can be seen that the majority of the professors interviewed felt that the possibility of improving the electric service through the application of solar energy technology is high. The specialists stated that electricity generation systems taking advantage of solar energy, are based on the ability of photovoltaic cells to transform the light radiation of the Sun into electrical energy in the form of direct current (DC). This means that the consumption of any other fuel for generation is zero and therefore $\mathrm{CO}_{2}$ emissions are practically symbolic. In a system connected to the network, the energy through the use of an inverter is transformed into alternating current, which can be used in homes or institutions with the capacity to avoid fossil fuels to generate electricity and improve the network's voltage profile together with other benefits that are only achieved with the use of solar energy in the distributed generation mode (Quijije and Reina, 2015). The above was corroborated through the development of a research project carried out at the FCMFQ, since the end of 2015 and the beginning of 2016, with the title: "Implementation of a photovoltaic micro-network connected to the low voltage network, to supply electrical energy to the first floor of building No. 3 of full-time teachers of the UTM, saving and energy efficiency (Intriago and Salvatierra, 2015), where measurements were made with a network analyzer before and after connecting the photovoltaic system and as a result it was found that after the installation of the technology, the voltage and stability profile of the energy in the network was benefited during the day hours when solar energy is available. Considering the above, it can be defined that the introduction of solar energy in the technical form of connection to the low voltage network, taking advantage of the distributed generation mode, can achieve oil savings, reducing the electric bill of the institution and at the same time contribute to the reduction of $\mathrm{CO}_{2}$ emissions into the atmosphere.

At present, it is known the reducing effect that favors the introduction of the photovoltaic technology connected to the network, for the energy consumption of the conventional system. There are results of research carried out in the UTM (Intriago and Salvatierra, 2015) that show that more than $90 \%$ of the electric 
power consumption in the institution is done during the day when the solar potential is available to be used. The university must pay CNEL 0.07 cents for each kWh consumed. At the end of February 2016, a small 3.4 $\mathrm{kWp}$ photovoltaic power plant connected to the low voltage network of the installation was installed on the roof of building No. 3 of the full-time teachers of the UTM (Intriago and Salvatierra, 2016). To date, this small renewable power plant has generated more than $8 \mathrm{MWh}$ of electricity, having saved in a year some 560.00 USD for electricity bill concept. It is important to consider that the electric energy consumed in the university has a thermal origin, with a real cost of kWh served over USD 0.30 , so the main impact can be for the Ecuadorian state. The small photovoltaic plant referred to above has led to a year of operations, an economic saving for the Ecuadorian state equivalent to 2,400.00 USD.

To define the economic savings for the reduction of the electric bill, equation 2 was used.

$$
R f e=E f v G \cdot \operatorname{Pr} E
$$

Where:

Rfe $\rightarrow$ amount of the reduction of the electric bill (USD)

EfvG $\rightarrow$ photovoltaic energy generated and incorporated into self-consumption (kWh)

PrE $\rightarrow$ referential price of energy (USD / kWh)

The equation (3) was used to define the economic savings to the state for a photovoltaic generation.

$$
A e E=E f v G+P e \cdot C E
$$

Where:

AeE $\rightarrow$ economic savings for the state (USD)

$\mathrm{Pe} \rightarrow$ avoided energy losses (kWh)

$\mathrm{CE} \rightarrow$ actual cost of thermal energy served to users (USD / kWh)

In recent years there has been a take-off of photovoltaic installations in cities of the first world, since the photovoltaic market is suffering a strong annual increase worldwide, where photovoltaic systems connected to the electricity grid have reached such a development that you can find large photovoltaic power plants, which generate powers of the order of MW. Hemau head office in Germany with a power of 4 MWp topped this list; accompanied by others such as Serre in Italy with $3.3 \mathrm{MWp}$; that of Munich with $2 \mathrm{MWp}$ and that of Toledo of $1 \mathrm{MWp}$, among others (Rodriguez, 2015). Photovoltaic technology connected to the low voltage network has potential to reduce losses; save natural resources; reduce the amount of the electric bill; decrease $\mathrm{CO}_{2}$ emissions to the atmosphere and; improve the electric service in the place where it is installed (Quijije and Reina, 2016)

The new teaching building of the FCMFQ, basically develops its teaching activities in the daytime, so that more than $85 \%$ of the energy consumption of the institution is concentrated in the hours that solar radiation is available to be used for generation of electricity. The consumption of electricity is motivating the institution to cancel monthly to the company CNEL an electricity consumption bill that in recent months has experienced an increase, so the university authorities have been projected to find a solution that manages to reduce the amount of said invoice.

Subsection should be written without a bold type. The result and analysis are presented by present form. Please avoid too many paragraphs in this section. As part of the realization of the investigation, a study of the load of the building was carried out, for which an inventory of the consuming equipment and the calculation of the daily consumption was made. To estimate the energy consumption by equipment, the coincidence factor was determined, which indicates the estimated percentage that is considered so that the equipment is consuming energy at the same time as the rest of the electrical equipment.

The average power demand was determined by applying equation (4).

Alava, L. A. C., Castillo, G. A. L., Macias, J. C. M., Segarra, J. C. G., \& Molina, L. A. V. (2018). Energy analysis for designing photovoltaic power plant in building of the faculty of mathematics. International Journal of Physical Sciences and Engineering, 2(3), 10-22. https://doi.org/10.29332/ijpse.v2n3.192 
$D P p=P i . F C$

Where:

DPp $\rightarrow$ average power demand $(\mathrm{kW})$

$\mathrm{Pi} \rightarrow$ installed power $(\mathrm{kW})$

$\mathrm{Fc} \rightarrow$ match factor $(\%)$

The utilization factor is a numerical value that has been estimated to indicate the percentage of time that each team will be consuming energy, determined by the analysis of the probable schedule during the day. For the calculations of the installed power $(\mathrm{W})$, the inventory of each equipment by type with its unit nominal power and the amount of equipment that exists was considered, and equation (5) was applied.

$$
\mathrm{P}=\text { Ce.Pnu }
$$

Where:

$\mathrm{P} \rightarrow$ power $(\mathrm{kW})$

$\mathrm{Ce} \rightarrow$ quantity of equipment $(\mathrm{U})$

$\mathrm{Pnu} \rightarrow$ unit rated power $(\mathrm{kW})$

To estimate the daily work hours, equation (6) was applied.

$$
h T=C e . P n u
$$

Where:

$\mathrm{hT} \rightarrow$ hours of work (h)

$\mathrm{Fu} \rightarrow$ utilization factor (\%)

$\mathrm{hD} \rightarrow$ daily hour (12)

To define the estimate of energy consumption, equation 7 was applied, which would be valid for working days, since it is known that the center ceases its work on weekends and during the vacation period.

$$
C e=h \cdot D P p
$$

Where:

$\mathrm{Ce} \rightarrow$ estimated energy consumption (kWh)

$\mathrm{h} \rightarrow$ working hours $(\mathrm{h})$

$\mathrm{DPp} \rightarrow$ average power demand $(\mathrm{kW})$

The results of the load study showed that in a normal working day, an average of $2157 \mathrm{kWh}$ can be consumed, of which $1926 \mathrm{kWh}$ are consumed in daytime hours when solar energy is available to be used, this represents $89 \%$ of the total energy consumed in a day. Figure 2 shows a graph of the hourly behavior of the estimated electricity consumption in the new building of the Faculty of Mathematical, Physical and Chemical Sciences of the UTM. 


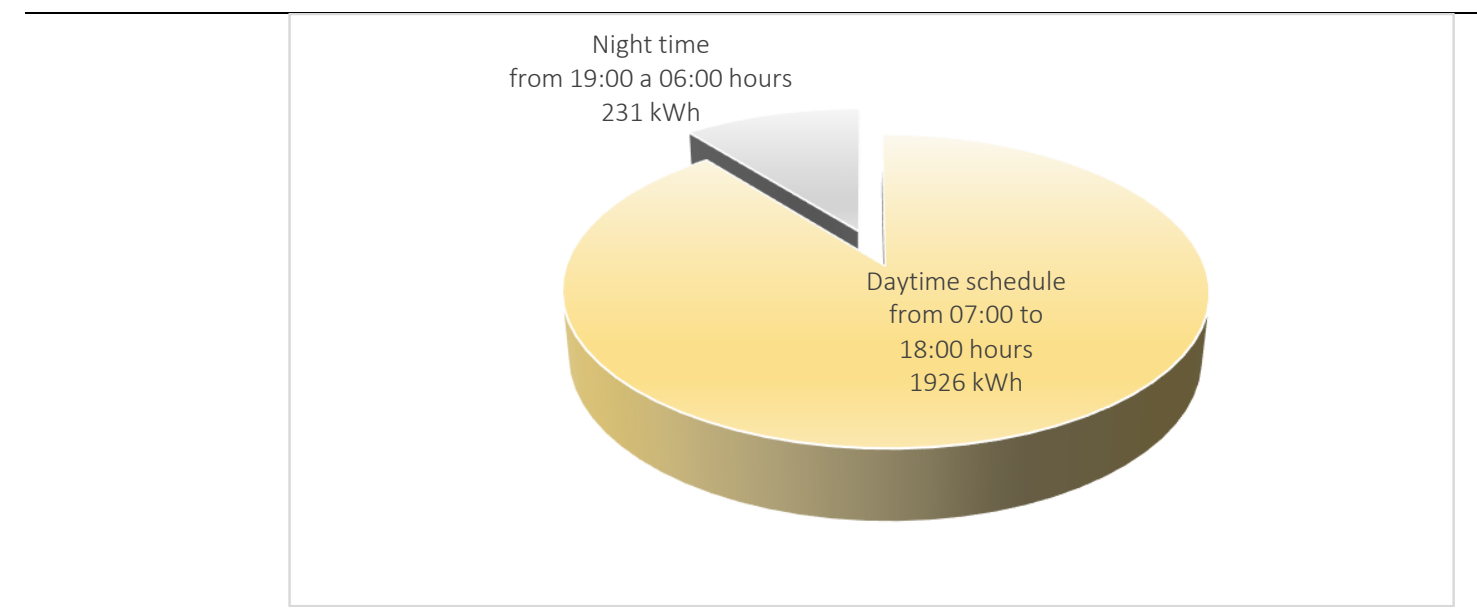

Figure 2. The hourly behavior of the electric power consumption estimate

\subsection{Study of solar potential}

Another work that needs to be done to design a photovoltaic installation that will be installed in an institution, is related to the study of solar potential at the installation site. Table 1 shows the calculation of the average solar radiation by months of the incident year in the site where the new building of the FCMFQ of the UTM is located.

Table 1

Average solar radiation by months of the year

\begin{tabular}{lllllllllllll}
\hline $\begin{array}{l}\text { Annual } \\
\text { Average }\end{array}$ & January & February & March & April & May & June & July & August & September & October & November & December \\
\hline 4,347 & 4,722 & 4,668 & 5,274 & 5,176 & 4,686 & 3,635 & 3,564 & 3,768 & 4,000 & 4,045 & 4,125 & 4,499 \\
\hline
\end{tabular}

\section{Calculation of the power needed to install}

Another data that is necessary to calculate is that related to the normalized productivity and has been done using equation (8).

$$
P n=P s p a . P F V . A c c . \eta \mathrm{t} . \eta \mathrm{c}
$$

Where:

$\mathrm{Pn} \rightarrow$ normalized productivity (kWh / kWp day)

$\mathrm{Pspa} \rightarrow$ annual average solar potential (kWh $/ \mathrm{m}^{2}$ day)

$\mathrm{PFV} \rightarrow$ photovoltaic power (kWp)

Acc $\rightarrow$ solar collection area of photovoltaic cells $\left(6.4 \mathrm{~m}^{2}\right)$

ht $\rightarrow$ technical efficiency of the modules (in the case of polycrystalline silicon it is equal to $13 \%$, in the case of monocrystalline silicon it is equal to $16 \%$ )

$\eta \mathrm{c} \rightarrow$ average efficiency of radiation uptake during the life cycle (86\%)

Table 2 shows the calculation of the normalized productivity for the place where the new building of the Faculty of Mathematical, Physical and Chemical Sciences is located, according to the incident solar radiation in the months of the year.

Alava, L. A. C., Castillo, G. A. L., Macias, J. C. M., Segarra, J. C. G., \& Molina, L. A. V. (2018). Energy analysis for designing photovoltaic power plant in building of the faculty of mathematics. International Journal of Physical Sciences and Engineering, 2(3), 10-22. https://doi.org/10.29332/ijpse.v2n3.192 
Table 2

Calculation of normalized productivity

\begin{tabular}{lllllllllllll}
\hline $\begin{array}{l}\text { Annual } \\
\text { Average }\end{array}$ & January & February & March & April & May & June & July & August & September & October & November & December \\
\hline 4,347 & 4,722 & 4,668 & 5,274 & 5,176 & 4,686 & 3,635 & 3,564 & 3,768 & 4,000 & 4,045 & 4,125 & 4,499 \\
\hline
\end{tabular}

In this way, it was possible to verify that, as an annual average, $\mathrm{Pn}=4,347 \mathrm{kWh} / \mathrm{kWp}$ day.

\subsection{Market research}

One of the internationally recognized barriers for the penetration of photovoltaic systems results in the prices that photovoltaic technologies had been experiencing in the market in previous years. At present, the reduction in prices, the increase in quality and the estimated lifespan of these technologies place it within the competition of the energy market with a very good positioning (Stolik, 2015). However, here in Ecuador, the price of photovoltaic energy is still high and it is not greatly reduced even though the government has decided to free tariffs on these technologies for their entry into the country.

It has been verified by the commercial offer made by the private company ARPRO Industrial SA, located in Manta, province of Manabí (in Annex 2 the commercial offer referred to above is attached), that the kWp of photovoltaic for connection to the network is quoted currently facing the Ecuadorian market at about 3.36 dollars, in relation to the price of 1.70 dollars that is quoted in the international market led by China. This is a situation that is holding back the application of photoelectric exploitation technologies in the province of Manabí.

It is known that the objective of the introduction of photovoltaic technology in the building of the FCMFQ, is to reduce the consumption of electricity of the conventional network in more than $80 \%$ approximately and if it is considered that the average consumption of electrical energy in a day The institution's lecture can be about 2157 MWh day and knowing that this total can be consumed in the hours when the solar radiation is available to be used $1926 \mathrm{kWh}$ day and that the average normalized productivity in the place where the new building can be equal to $4,347 \mathrm{kWh} / \mathrm{kWp}$ day, you can calculate the power that is required to install to reduce the amount of the electric bill. To calculate the photovoltaic power that is required to install, equation (9) was used. Checking that to cover this consumption it is necessary to install a photovoltaic power plant with a power equivalent to $443 \mathrm{kWp}$.

$$
P f v N i=\frac{E c e a}{P n a}
$$

Where:

PfvNi $\rightarrow$ Photovoltaic power needed to install (kWp)

ECea $\rightarrow$ Estimated daytime electricity consumption in one year (kWh day)

Pna $\rightarrow$ Normalized productivity in one year (kWh / kWp day)

In this way, it can be estimated that the photovoltaic power that is required to be installed in the new building of the Faculty is $443 \mathrm{kWp}$. With these obtained energy results, the photovoltaic power plant can be designed for the building of the faculty, this can be installed in a modular way as the loads are growing so that each module that is incorporated in the generation is energy that is left behind. Consume with the generation of fossil fuels and in turn, stop emitting polluting gases into the atmosphere. 


\section{Conclusion}

The intensity, quality, and availability of solar potential throughout the year at the site where the new building of the UTM, CFMFQ is located, allows the introduction of photovoltaic technology to generate electricity, with a competitive performance with any other technologies and existing generation sources. It is viable from the technical, economic, environmental, and social point of view, to introduce the photovoltaic technology connected to the low voltage network of the faculty, with the aim of reducing by $89 \%$ the amount of the electricity bill derived from the energy consumption of the conventional network. The introduction of photovoltaic technology can generate other benefits associated with the protection of natural resources by avoiding the consumption of 175.6 tons of oil per year, as well as avoiding the emission of 632 tons of $\mathrm{CO}_{2}$ into the atmosphere in the same period of time weather.

\section{Acknowledgments}

This research has been made in the interest of changing the image of the UTM, educating students on the efficient use of energy and the use of renewable sources. 


\section{References}

Arauz, W. M. S., Cede $\tilde{ \pm} \pm$, G. I., \& Antonio, V. Ã. (2017). Microgrid With a 3.4 kWp Photovoltaic System in the Universidad TÃ $($ c cnica de ManabÃ. International Journal of Physical Sciences and Engineering, 1(2), 11-20. https://doi.org/10.21744/ijpse.v1i2.34

Arauz, W. M. S., Gámez, M. R., Pérez, A. V., \& Fernández, M. C. (2016). Microgrids Views from a Geographic Information System. System, 2454, 2261. https://www.researchgate.net/profile/Maria_Rodriguez_Gamez/publication/319532870_308-3751/data/59b1af43458515a5b4893e46/308-375-1.pdf

Cabeza, C. J. V. (2018). Estudio del potencial disponible en el edificio 3 para aumentar la generación por energía solar. Facultad de Ciencias Matemáticas, Físicas y Químicas. trabajo de titulación previo para obtener el título de Ingeniero Electricicsta, Repositorio de la biblioteca de la Universidad Técnica de Manabí. http://repositorio.ug.edu.ec/handle/redug/19861

Cedeño, M. L. D., Arteaga, M. G. D., Pérez, A. V., \& Arteaga, M. L. D. (2017). Regulatory Framework for Renewable Energy Sources in Ecuador Case Study Province of Manabí. International Journal of Social $\begin{array}{llll}\text { Sciences } \quad \text { and 29-42. } & \text { (IJSSH), 1(2), }\end{array}$ https://sciencescholar.us/journal/index.php/ijssh/article/view/33

Chilan, J., Pérez, A., Gámez, M., García, A., \& Breffe, 0. (2017). Use of Small Wind Turbines in Isolated Areas Social Impact. International Research Journal of Engineering, IT \& Scientific Research, 3(2), 84 90. https://doi.org/10.21744/irjeis.v3i2.415

Gámez, M. R., Pérez, A. V., Será, A. S., \& Ronquillo, Z. M. (2017). Renewable Energy Sources and Local Development. International Journal of Social Sciences and Humanities (IJSSH), 1(2), 10-19. https://sciencescholar.us/journal/index.php/ijssh/article/view/31

Giraudy Arafet, C. M., Massipe Cano, I., Rodríguez Rivera, R., Rodríguez Gámez, M., \& Vázquez Pérez, A. (2014). Factibilidad de instalación de sistemas fotovoltaicos conectados a red. Ingeniería Energética, 35(2), 141148. http://scielo.sld.cu/scielo.php?pid=S1815-59012014000200007\&script=sci_arttext\&tlng=pt

Intriago, C.G. and C.S. Salvatierra, (2015) Implementación de tecnología fotovoltaica conectada a la red para suministrar energía eléctrica al segundo y tercer piso del edificio no 3 de docentes a tiempo completo de la Universidad Técnica de Manabí, el ahorro y la eficiencia energética. Facultad de Ciencias Matemáticos, Físicas y Químicas de la Universidad Técnica de Manabí, 2015. Disponible en el repositorio de la biblioteca de la Universidad Técnica de Manabí. http://repositorio.utm.edu.ec/bitstream/123456789/1090/1/TESIS.pdf

Intriago, C.G. and C.S. Salvatierra, (2016). Implementación de tecnología fotovoltaica conectada a la red para suministrar energía eléctrica al segundo y tercer piso del edificio no 3 de Docentes a Tiempo Completo de la Universidad Técnica de Manabí, el ahorro y la eficiencia energética. Proyecto de Titulación previo a la obtención Del Título de Ingeniero Eléctrico, 2015. Repositorio de la Biblioteca de la Universidad Técnica de Manabí. http://parlana.secom.gob.ec/sites/default/files/boletines/524601ec693ff.pdf

María, R. G. (2015). Sistema de Información Geográfica para el Desarrollo Sostenible"(SIGDES). Facultad de Ciencias Matemáticas, Físicas y Químicas de la Universidad Técnica de Manabí.

Medveczky, O.D. and C.J. Ochoa, (2012). Tesis previa a la obtención de título de ingeniero eléctrico. Universidad de Cuenca. http://www.ups.edu.ec/ups-portal-general-datos-graduado-detalleportlet/PDF/UPS-DatosGraduado-107228-ES-ochoa_mendez_andres_esteban.pdf

Murray R. Spiegel and Larry, Stephens (2009). Estadística. McGRAW-HILL/INTERAMERICANA EDITORES, S.A. de C.V. Cuarta edición. ISBN: 978-0-07-148584-5. Impreso en México. https://clea.edu.mx/.../Spiegel\%20Murray\%20-\%20Probabilidad\%20Y\%20. Estadistica

Pérez, A., Castillo, G., Alava, L., \& Chilan, J. (2016). The Regulatory Framework for Renewable Energy Sources. International Research Journal Of Management, IT \& Social Sciences, 3(11), 7 - 19. https://doi.org/10.21744/irjmis.v3i11.302

Pérez, A., Gámez, M., Viteri, C., \& Quiroz, A. (2017). Community Power as a Driving Force for Sustainable Local Development.International Research Journal of Engineering, IT \& Scientific Research, 3(4), 7-17. https://doi.org/10.21744/irjeis.v3i4.489

Quijije A Wilson S and Reina V Jefferson D, (2016). Implementación de una microrred fotovoltaica conectada a la red, para suministrar energía eléctrica al primer piso del edificio no. 3 de Docentes a Tiempo Completo de la Universidad Técnica de Manabí, el ahorro y la eficiencia energética. Informe escrito del trabajo de 
titulación para obtener el Título de Ingeniero Eléctrico. Modalidad de Trabajo Comunitario y Cambio de la Matriz Energética. Repositorio de la Biblioteca de la Universidad Técnica de Manabí. http://repositorio.utm.edu.ec/bitstream/123456789/1090/1/TESIS.pdf

Quijije, A.W.S. and V.J.D. Reina, (2015) Implementación de una microrred fotovoltaica conectada a la red, para suministrar energía eléctrica al primer piso del edificio No. 3 de docentes a tiempo completo de la UTM, el ahorro y la eficiencia energética. Repositorio de la biblioteca de la Universidad Técnica de Manabí. http://www.editrade.cl/indicadores-utm-2014.php

Ramos, J., Pérez, A., Gámez, M., \& Zambrano, R. (2018). Renewable energy sources on the change of energy matrix in Manabí province.International Research Journal Of Engineering, IT \& Scientific Research, 4(4), 17 29. Retrieved from https://ijcu.us/online/journal/index.php/irjeis/article/view/696

REN 21, Reporte de la situación mundial de las energías renovables (2015). Hallazgos claves 2015. Renewable energy polici network. ISBN 978-3-9815934-7-1, 2015. http://www.ren21.net/wpcontent/uploads/2018/06/17-8652_GSR2018_FullReport_web_-1.pdf

Rodríguez Gámez, M., Vázquez Pérez, A., Castro Fernández, M., \& Vilaragut Llanes, M. (2013). Sistemas fotovoltaicos y la ordenación territorial. Ingeniería Energética, 34(3), 247-259. http://scielo.sld.cu/scielo.php?script=sci_arttext\&pid=S1815-59012013000300008

Rodríguez Gámez, M., Vázquez Pérez, A., Castro Fernández, M., \& Vilaragut Llanes, M. (2013). Sistemas fotovoltaicos y la ordenación territorial. Ingeniería Energética, 34(3), 247-259. http://scielo.sld.cu/scielo.php?script=sci_arttext\&pid=S1815-59012013000300008

Sarmiento Sera, A., Rodríguez Gámez, M., Castillo Castillo, O., \& Vázquez Pérez, A. (2014). Sistemas Integrados de energías con fuentes renovables, requisitos y opciones. Ingeniería Energética, 35(1), 70-78. http://scielo.sld.cu/scielo.php?pid=S1815-59012014000100008\&script=sci_arttext\&tlng=pt

Soto I E, Celdas fotovoltaicas en la generación distribuida. Santiago de Chile. Tesis Consultado diciembre (2015). http://web.ing.puc.cl/power/paperspdf/pereda.pdf

Stolik, D., (2015). Proposición de proyecto de programa nacional para el desarrollo de la energía fotovoltaica en Cuba. Proyecto resumido. Unión Eléctrica (UNE) Ministerio de Energía y Minas de Cuba, 2012. https://www.climateeval.org/sites/default/files/evaluations/513\%20Photovoltaic\%20Based\%20Rural\%20Electrification.pdf

Van, D. W. (2002). La cooperación transnacional, un instrumento al servicio del desarrollo rural. Cooperación internacional entre territorios rurales. Consultado diciembre 2017. Disponible en: http://ec.europa.eu/agriculture/rur/leader2/rural-es/coop/coop1.pdf.

Alava, L. A. C., Castillo, G. A. L., Macias, J. C. M., Segarra, J. C. G., \& Molina, L. A. V. (2018). Energy analysis for designing photovoltaic power plant in building of the faculty of mathematics. International Journal of Physical Sciences and Engineering, 2(3), 10-22. https://doi.org/10.29332/ijpse.v2n3.192 


\section{Biography of Authors}

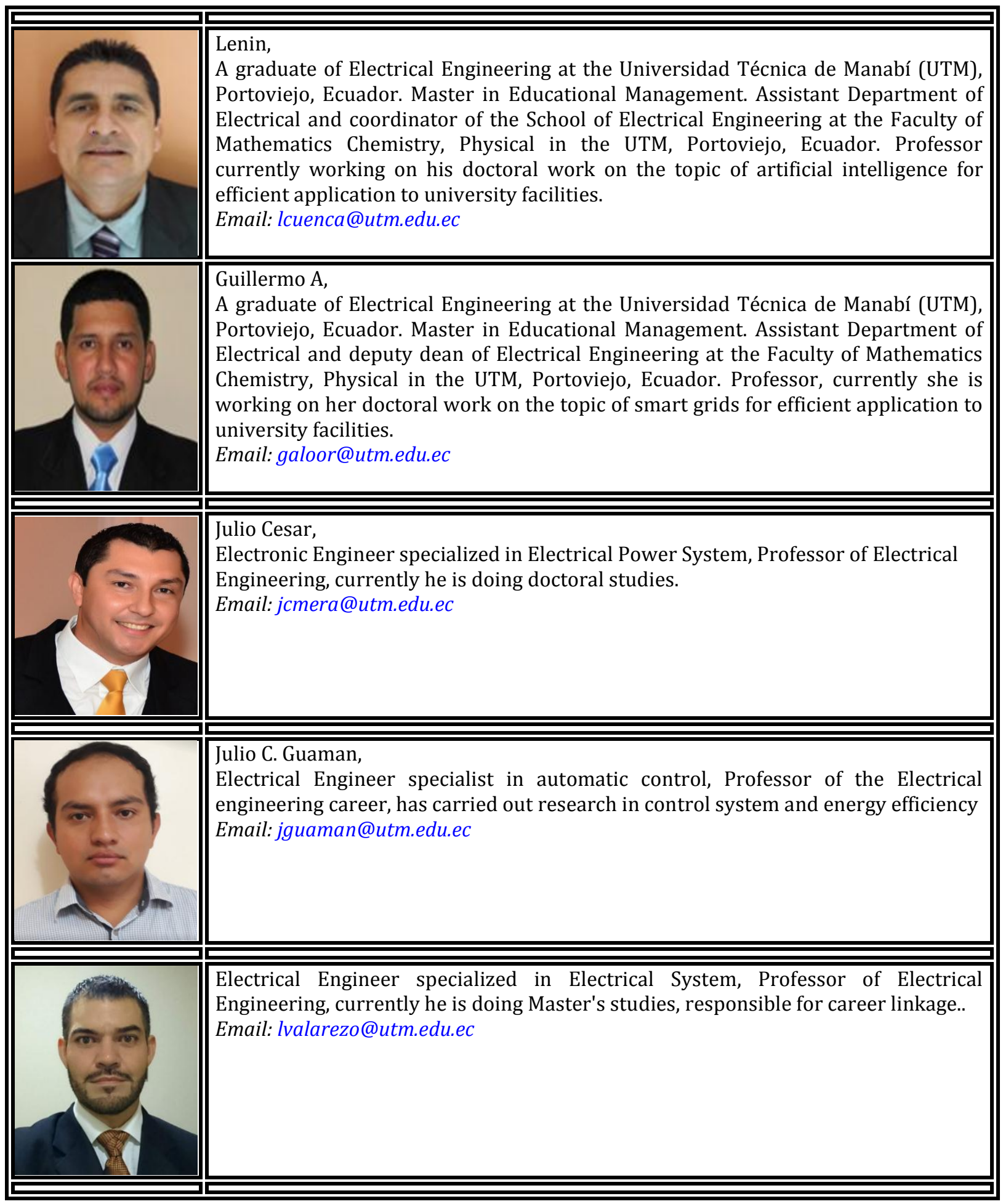

